\title{
Performance Management System of Jordanian Public Sector Organizations: Greater Amman Municipality's (GAM) Experience
}

\author{
Mo'men Hani Mahmoud (Corresponding author) \\ Graduate School of Business, Universiti Sains Malaysia, \\ 11800, Penang, Malaysia \\ E-mail: moumen.mahsere@yahoo.com \\ Rosly Othman \\ Graduate School of Business, Universiti Sains Malaysia, \\ 11800, Penang, Malaysia \\ E-mail: roslyothman@yahoo.com \\ Mohammed Al Taher Mahmoud \\ Maastricht School of Management, \\ 13104, Kuwait City, Kuwait \\ E-mail: mohammed.altaher@gmail.com
}

Received: April 26, 2020 Accepted: May 31, 2020 Online published: June 2, 2020

doi:10.5296/ijhrs.v10i2.16915

URL: https://doi.org/10.5296/ijhrs.v10i2.16915

\begin{abstract}
The Performance Management System (PMS) is one of the most critical systems within the context of public organizations. Without proper implementation of the PMS, these organizations will encounter challenges to deliver their services. Ideally, the PMS framework might cover several fields, including strategic planning and goals setting, strategies and plans, performance appraisal, the reward and punishment system, and performance information. Due to limitations in the existing literature about the PMS in the developing countries, this paper aims to reflect on the implementation of the PMS in the Greater Amman Municipality
\end{abstract}


(GAM) in Jordan because it is one of the biggest employers of the Jordanian public sector in the Middle East region, which is an integral part of the developing contexts. To this end, a descriptive analysis of the secondary data has been conducted, including the related literature, published documents, and archival data. According to Otley's (1999) framework and the analysis of the experiences of the PMS of public entities in the developing world, the GAM system has failed to implement the performance indicators formulation. Also, its indicators are excessively reliant on archival measures. The GAM system is missing out on two major processes, which are appraising performance and the reward and punishment system. The findings revealed that the GAM system has failed to consider the results of the community satisfaction survey as a valuable source of performance for the performance inputs and planning process. Accordingly, a comprehensive framework of PMS has been synthesized and introduced in this paper.

Keywords: Performance Management System (PMS), Performance Measurements, Jordanian Public Sector, Greater Amman Municipality (GAM)

\section{Introduction}

The Jordanian public sector represents one of the biggest public sectors in the Middle East countries. It consists of (30) ministries, institutions, and other public entities that are managerially related to the Prime Minister of Jordan; the number of ministries in other public sectors in this region is (18) ministries. This big number of ministries, institutions, and public entities has contributed to raising the number of public staff members in this sector to (218) thousand employees. Such a number has created various challenges related to managing and enhancing the performance of the Jordanian public sector, as well as other challenges, which hindered solutions to several issues such as corruption, high expenditures, and personal benefits. Other challenges, which are specially generated in Amman city, hindered the achievement of citizens' satisfaction of services delivered due to the influx of immigrants because of the Iraqi crisis at the beginning of 2003, in addition to the Syrian crisis at the beginning of 2011. It is worth mentioning that most of the Iraqi and Syrian immigrants have settled in the capital city of Jordan, Amman, which resulted in high demands for public services (JESC, 2018).

Regarding GAM services, (4) million citizens in Amman from a total of (9) million citizens in Jordan receive their public services in the areas of infrastructure, environmental services, social development, logistics, and public health services through GAM (Muath, 2016). GAM is led by the Mayor of Amman, who directly reports to the Prime Minister of Jordan. GAM includes (23) thousand employees, and it is one of the biggest public employers in Jordan (World Bank, 2017) (i.e., it embraces more than (10\%) of Jordanian public staff). Accordingly, considering GAM's experience of the performance management system (PMS) can be regarded as a valuable source of Jordanian public sector organizations in order to highlight PMS in the context of the Middle East region as a key component of the developing world. It has been confirmed by scholars that the existing literature about performance management is very limited, particularly in the developing countries' context (Janjua et al., 2019) together with the managerial transformation, which is underway in the Middle East region (Budhwar et al., 2019).

To this end, this paper uses the descriptive and analytical methods of the secondary data, which 
were adopted by previous scholars in studying the local government's PMS in Indonesia (Jurnali \& Siti-Nabiha, 2015), as well as improving the government's PMS in South Korea (Roh, 2018). This paper aims to review the related literature regarding the systems of local and central agencies in the developing world. Moreover, the paper aims to review the published documents, plans, guidelines, and regulations about the PMS of GAM as one of the biggest public employers of the Jordanian public organizations. The paper aims to investigate the performance management and governmental regulations, which manage and regulate the GAM system to reflect on its experiences and problems or gaps in the GAM system.

This paper is organized into six sections. The first section reviews the Performance Management System (PMS) of public organizations to highlight the PMS framework. The second section reviews the experiences of the PMS in the developing world. The third section highlights the Greater Amman Municipality's (GAM) context. The fourth section describes the GAM system. The fifth section evaluates the PMS of GAM. The synthesis of a comprehensive PMS framework and the conclusion are provided in the sixth section of this paper.

\section{Performance Management System (PMS) of Public Organizations}

The performance management concept has been developed by introducing New Public Management (NPM) reforms into public organizations (Modell, 2015). This concept strives to improve the performance of public organizations according to four major aspects, including what do organizations measure, how do they measure, data interpretation, and communicating the results (Fryer et al., 2009; Roh, 2018). However, scholars mentioned that although authors use performance management and measurement concepts interchangeably, these concepts cover different purposes. Performance management seeks to provide data and information related to future performance. On the other hand, performance measurement is used as tools and methods to gauge previous performance (Fryer et al., 2009; Radnor \& Barnes, 2007). Accordingly, performance management is defined as a system that establishes performance information and data through processes, which rely ideally on strategic planning and performance measurement to link the information and data of performance with decision-making positions (i.e., accountability) (Janjua et al., 2019). In contrast, performance measurements are the tools and methods (i.e., performance indicators) that aim to gauge the achievement of objectives and strategic goals concerning the translation of effectiveness and efficiency concepts (Roge \& Lennon, 2018). Moreover, scholars mentioned that measuring efficiency (i.e., outputs), particularly in public organizations, is more significant than measuring effectiveness (i.e., outcomes) (Jurnali \& Siti-Nabiha, 2015). In other words, public organizations are not operated for profit, and the strategic goals of these organizations are mostly non-financial goals (i.e., public services) and, therefore, they might pose an ambiguity (Arnaboldi et al., 2015; Roge \& Lennon, 2018).

Accordingly, any PMS might include several concepts, which should be considered in public organizations, including accountability, efficiency, and effectiveness. Also, these concepts should be carefully embedded with the PMS activities, including inputs, processes, outputs, and outcomes, as well as strategic planning and goals' designing (Arnaboldi et al., 2015; Fryer et al., 2009; Janjua et al., 2019; Roge \& Lennon, 2018). Furthermore, performance 
inputs might be described as resources or data that are used to achieve the strategic goals. Performance processes might interpret all strategies, action plans, and procedures used to implement organizational goals through KPIs. Eventually, both outputs and outcomes might reflect the efficiency and effectiveness of performance in a way that might elaborate on the performance results of the achieved goals (Jurnali \& Siti-Nabiha, 2015). Scholars have classified the performance indicators into two types, including archival and perceptual indicators (Andersen et al., 2015; Favero \& Bullock, 2014). That is, the variations between these types of indicators are attributed to the degree of the criterion, which is related to the experiences and perceptions versus exterior and observable phenomena (Song \& Meier, 2018). Accordingly, archival indicators refer to these indicators that are related to the official indicators and administrative records of public organizations' performance. Alternatively, perceptual indicators refer to the indicators, which are related to the efforts of the stakeholders' contributions to improve the performance of public organizations (Andersen et al., 2015; Favero \& Bullock, 2014), whether they are internal stakeholders (i.e., public staff) or external stakeholders (i.e., citizens) (Spekle \& Verbeeten, 2014). Scholars have also stated that the archival indicators might not help in improving the quality of services delivered to the citizens. On the other hand, the perceptual indicators are widely used because they might be able to consider important dimensions of the performance, which might be neglected by the archival indicators (Song \& Meier, 2018).

However, the archival and perceptual indicators alike need to be cautiously put in the contexts of public organizations. Otherwise, public organizations might be encountered with ambiguity in their indicators and strategic goals (Spekle \& Verbeeten, 2014). Therefore, scholars strongly confirmed that clarity of performance indicators needs to dispose of three problems that might face performance indicators of public organizations, which are imposed by the government's legislation and rules. These issues include 1) technical problems, which are related to the lack of collecting, analyzing, interpreting, validating, reporting, and quality of performance indicators, 2) system problems, which reflect the poor integration of performance indicators, lack of strategic focus, ambiguous goals, and the high PMS budget, and 3) involvement problems, which highlight the lack of stakeholders' involvement in the performance indicators formulation such as the lack of citizens' involvement (i.e., citizens' feedback) and the lack of public staff involvement (Andersen et al., 2015; Fryer et al., 2009; Rautiainen et al., 2017). Other issues of performance indicators, which were also elaborated by scholars, include the manipulation of the performance indicators. In this respect, scholars mentioned that there are public managements, which have planned ambiguous indicators to exceed the budget allocation of the PMS, which, in turn, take a form of corruption, as well as the responsibility evasion (Verbeeten, 2008). The PMS of the municipal entities, which are managed and regulated by governments, might also encounter other challenges. These challenges can be attributed to the lack of critical elements, which are related to performance such as the organizational structure, alignment, planning, reporting, accountability, data of performance, change of minds and ownership, human resources, and capacity of performance (Goh et al., 2015).

Several frameworks were theoretically developed and proposed by scholars to address the PMS issues and tackle PMS in the contexts of public organizations properly. However, PMS 
experiences in developing world are very limited (Janjua et al., 2019). Jurnali and Siti-Nabiha (2015) relied on Otley's (1999) framework to reflect on the Indonesian experience by highlighting the PMS for the local government in Indonesia. This framework covers five major fields so that good results of performance can be achieved. These fields are: First, organizational goals and objectives, including methods and tools to gauge their achievement. Second, strategies, sub-strategies, and plans used to implement organizational processes and activities. Third, performance appraisal to evaluate performance results. Forth, rewards and punishment system to reward good results and punish bad results. Fifth, the information flow that covers performance feedback of the organization's experience to obtain feedback about the provision of public services that are delivered by these public organizations for the community (Otley, 1999).

In the same vein, the PMS framework of the Pakistani local government has been discussed by scholars. This framework is highlighted through four main fields, including organizational setup, performance indicators and benchmarks, analysis of performance information, and focus on performance management (Janjua et al., 2019). Generally, other scholars confirmed that the PMS framework of public organizations should cover five fields, including 1) PMS alignment with organizational strategies, 2) leadership commitment, 3) improving performance, including the evaluation process that can distinguish between good and bad performance, 4) stakeholder involvement (i.e., feedback), and 5) ongoing processes of monitoring, feedback, publishing, and learning (Andersen et al., 2015; Fryer et al., 2009; Goh et al., 2015). In addition to these fields of the PMS framework, public organizations need to tackle four main issues related to the performance measurements. These issues are what to measure, when to measure, interpreting the data, and communicating the results (Andersen et al., 2015; Fryer et al., 2009). Furthermore, Verbeteen (2008) has determined the PMS framework of public organizations in four practices, including defining strategic goals, selecting strategies and plans to achieve the goals, allocating decisions, and performance measuring and rewarding. These practices might provide managerial purposes, including communication, transparency, accountability, learning, and appraising purposes (Spekle \& Verbeeten, 2014; Verbeeten, 2008). Scholars have strongly confirmed that the success factors for implementing PMS might cover three significant dimensions, including clear vision and mission, performance management integration, and focus on capacity building, that explains the role of HRM to develop staff capacities to improve the performance outputs and outcomes (Goh et al., 2015).

In summary, public organizations should ensure that PMS covers five main fields to accomplish good results of their systems. First, strategic planning and goal setting, which help translate the organizational vision and mission. Second, strategies and plans, which are used to implement, measure, and allocate performance indicators, which, in turn, focus on effectiveness and efficiency. Third, performance appraisal, which is used to evaluate the staff performance to foster accountability of performance results. Fourth, the reward and punishment system, which is used to reward or punish the good or bad performance results. Fifth, performance information, which reflects publishing performance results internally and externally; it might be useful so that the organization learns from its experiences, collect 
valuable feedback from the stakeholders, and improve the overall performance (Goh et al., 2015; Fryer et al., 2009; Jurnali \& Siti-Nabiha, 2015; Otley, 1999; Verbeeten, 2008).

\section{Performance Management System (PMS) in the Developing Countries}

Research on successful PMS experiences of public institutions are generally very limited in developing countries (Janjua et al., 2019). Scholars confirmed that the existing literature about PMS, particularly in the developing countries is scarce and, therefore, further studies are needed to bridge the gap in the literature (Akbar et al., 2015). In the context of the developing world, the experiences of PMS should be highlighted to examine vital themes related to the fields of PMS framework through analyzing the positive and negative impacts of the implemented and unimplemented PMS fields. This will, in turn, provide further insights into the major fields, which are fundamental in achieving better results in the performance of public institutions (Andersen et al., 2016; Sutheewasinnon et al., 2016).

\subsection{The Pakistani System}

The PMS of the Pakistani experience has been reflected by the local governments in Khyber Pakhtunkhwa, which delivers its services in the fields of health, education, agriculture, municipal entities, sports and culture, social welfare, and population welfare. The PMS framework of the Pakistani context covers four major fields, including organizational setup, performance indicators and benchmarks, analysis of performance information, and focus on performance management.

The first field is the organizational setup field, which embeds budget allocation, supervision, performance reporting, feedback, and performance monitoring using the latest technological ways such as applications of smartphones. The second field is performance indicators and benchmarks field, whereby the Pakistani system includes more than (300) KPIs. These KPIs are designed using quantitative measures to achieve accurate results of performance. They are designed by the independent public sector experts and government officials. Other indicators are designed to check the effective use of the grants based on the "outputs-based budgeting model". In addition, the performance data is collected with close monitoring and discussed regularly with local stakeholders. The third field involves the analysis of performance information and the rigorous analysis of the collected performance data. One technique, which is used by the Pakistani system is benchmarking. Two levels of performance analysis are used in the Pakistani system, including provincial analysis level and the detailed examination of the performance of individual local governments. The provincial analysis uses the overall performance of each sector and compares it with previous targets. The detailed examination of the performance of individual local governments is compared with the performance of the sub-office with its previous performance, as well as with other similar sub-offices of the local government. The fourth field involves the focus on performance management, which focuses on performance management rather than performance measurement. Also, it focuses on the collected data of performance by all sub-offices of the local governments and evaluated by statistical and analytical tools. The results of performance evaluation are officially presented in the review meetings. The results are used in the decision-making process, and they are finally published online to the public (Janjua et al., 2019). 


\subsection{The Indonesian System}

The PMS of the Indonesian local government has been investigated by scholars, whereby it covers four major fields. These fields include strategic planning, performance measurement, performance reporting, and utilizing performance information. The first field in this system is strategic planning, which aims to achieve alignment with the vision, mission, goals, objectives, and strategies to expect future development of the local government performance. Also, it is translated into the performance planning process in two terms, including long and medium terms. The second field is the performance measurement; the performance measures of the Indonesian system are used to assess the success and failure of the implementation of strategies, processes, and activities using five levels of measures, including objectives, programs, activities, performance indicators, and performance targets. The third field is performance reporting, which focuses on performance outcomes and outputs of all strategies, processes, activities, and programs in two fields, including the performance measurements field and the performance information field. The fourth field of the Indonesian system is the performance information, which is used as a tool to improve the performance of local governments of this system. The inputs of the performance information field, which are the performance reporting and its outputs, are used as inputs of the strategic planning field as a process to develop the agencies' performance (Jurnali \& Siti-Nabiha, 2015).

\subsection{The Thai System}

The development process of the PMS of public organizations in Thailand involves four steps, including the development of the results based on the management system, office establishment of the public sector development commission, the framework of the performance development agreement, and refining and extending performance agreement. The first step is the development of the results based on the management system, which aims to simulate the imposed pressures to develop the Thai public sector performance, i.e., the achieved progress in creating measurable outcomes and outputs, and seeking to achieve transparency and responsiveness. For these major purposes, the administrative renewal project has been created to introduce effectiveness, efficiency, and evaluation of performance by adopting five components. They include introducing the results-based management system, a new government organization framework, rightsized civil services, improving human resource management, and establishing a senior executive development system. Accordingly, the results-based management system has adopted four perspectives, which should respond to several issues across each perspective as illustrated in Table 1.

Table 1. The perspectives of the results-based management system

\begin{tabular}{|l|l|}
\hline \multicolumn{1}{|c|}{ Perspective } & \multicolumn{1}{c|}{ Measurement } \\
\hline External perspective & Customer and government interests. \\
\hline Internal perspective & $\begin{array}{l}\text { Organizational behavior, processes, ability, motivation, skill, and } \\
\text { morale. }\end{array}$ \\
\hline Innovation perspective & Information, research, technology, and information networking. \\
\hline Financial perspective & $\begin{array}{l}\text { Economy, cost, cost-effectiveness, resource utility, and } \\
\text { anti-corruption. }\end{array}$ \\
\hline
\end{tabular}

Source: (Sutheewasinnon et al., 2016) 
The second step is the office establishment of the public sector development commission, the office of the public sector development commission has been separately established under the Prime Minister of Thailand. The purposes of establishing this office are to develop the performance management of public sector organizations in the Thai context, in addition to other responsibilities, including conducting research and studies, as well as monitoring and evaluating the ministries. The main goal of this body is to create cooperation and network between other institutions and organizations at all levels. It also aims to facilitate collaboration with all organizations and institutions inside and outside the country to accomplish the sustainable development of the public sector performance. The third step is the framework of the performance development agreement, which focuses on four fields. The first field of the Thai framework involves the results' collection of goals and mission. The second field involves gauging the public satisfaction of the services delivered, whereas the third field involves resource allocation and the reduction process. The fourth field is the development methods used to foster the performance of public organizations. These four fields can be explained by four perspectives as illustrated in Table 2 .

Table 2. The perspectives of the performance agreement

\begin{tabular}{|l|l|c|}
\hline \multicolumn{1}{|c|}{ Perspective } & \multicolumn{1}{|c|}{ Objective } & Weight \\
\hline $\begin{array}{l}\text { Effectiveness } \\
\text { of mission }\end{array}$ & Mission and goals achievements and work effectiveness. & $50 \%$ \\
\hline $\begin{array}{l}\text { Quality of } \\
\text { service }\end{array}$ & $\begin{array}{l}\text { Transparency of public administration and quality of services } \\
\text { based on the public satisfaction survey. }\end{array}$ & $10 \%$ \\
\hline $\begin{array}{l}\text { Efficiency of } \\
\text { operation }\end{array}$ & $\begin{array}{l}\text { The efficiency of work processes based on promptness, time, and } \\
\text { resource reduction in service delivery. }\end{array}$ & $10 \%$ \\
\hline $\begin{array}{l}\text { Organizational } \\
\text { development }\end{array}$ & $\begin{array}{l}\text { Organization's readiness for change based on human resource } \\
\text { management, knowledge management, information technology, } \\
\text { and change management }\end{array}$ & $30 \%$ \\
\hline
\end{tabular}

Source: (Sutheewasinnon et al., 2016)

The fourth step is refining and extending performance agreement, which covers the overall development and continuous improvements of the PMS in Thai public organizations. The major process that is developed in this step involves introducing self-assessment, which has been introduced as one of the KPIs to improve the government's managerial processes. Furthermore, the Thai government has introduced the Public Sector Management Quality Award (PMQA) to motivate high-performance management systems in the country so that excellent performance of public organizations can be achieved (Sutheewasinnon et al., 2016).

\section{Greater Amman Municipality (GAM) Context}

Greater Amman Municipality (GAM) is one of the biggest employers of Jordanian public sector organizations. The vision and mission of GAM concentrate on the provision of high-quality and excellent municipal services to its citizens in all walks of life without sacrificing its identity and the rich cultural heritage of Jordan (Municipality of Greater Amman, 2018). Up to date, GAM has employed more than (23) thousand employees (ZAYWA, 2018) from a total of (218) thousands of public staff of the Jordanian public sector (JESC, 2018). Moreover, it is a financially independent institution and it is managerially headed by the Mayor of Amman, who directly reports to the Prime Minister of Jordan (World 


\section{Macrothink}

International Journal of Human Resource Studies

ISSN 2162-3058 2020, Vol. 10, No. 2

Bank, 2017). GAM delivers five main public services in the capital city Amman in the fields of infrastructure, public health, environment, social development, and logistics. Additionally, its services are delivered to (4) million citizens in Amman city from a total of (9) million citizens in Jordan (Muath, 2016). GAM services are operated and managed by six main sectors, including the Public Works Affair Sector, the Public Health Affair Sector, the Environmental Affair Sector, the Social Development Affair Sector, the Economic Development Affair Sector, and the Financial and Administrative Affair Sector as shown in Figure 1 (GAM, 2015, P. 25). These sectors shoulder the responsibility of several duties to make Amman city an intelligent, attractive, livable, and economical city through implementing several projects such as urban planning, healthy disposing of waste, permit issuance, and so on. These projects are financially supported by the budget, which is allocated by the elected Municipal Council by Amman's community every (4) years (World Bank, 2017).

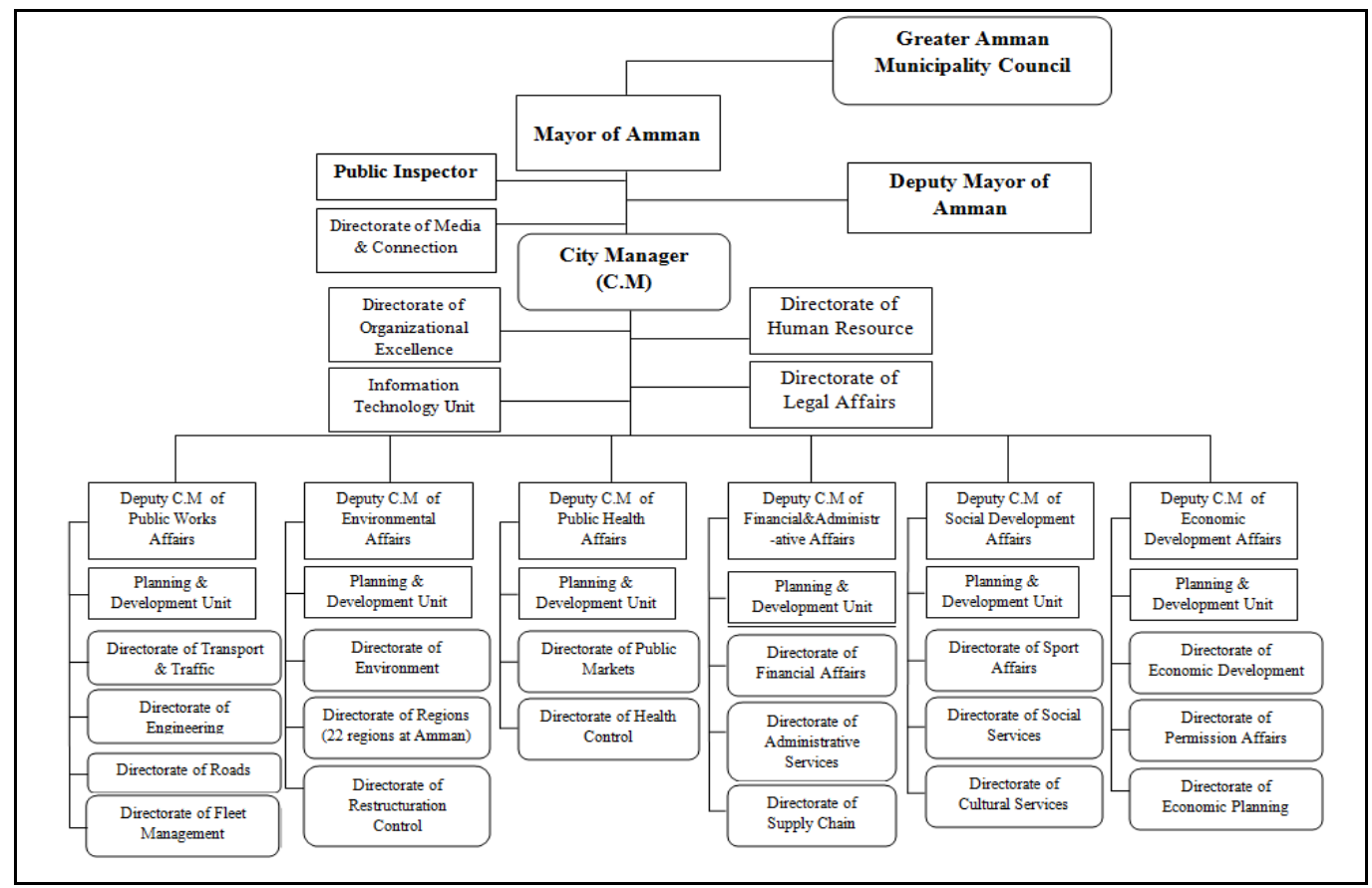

Figure 1. The Organizational Chart of GAM

Authors' Creation Based on GAM's Structure (GAM, 2015, P. 25)

\section{Performance Management System (PMS) in GAM}

The responsibility to achieve GAM vision and mission is related to the five administrative levels in the context of GAM as follows:

1. GAM Council: The GAM council is elected once every four years and it is headed by the Mayor of GAM. The responsibilities of this council are agreed-upon programs and projects, which are implemented in Amman city. It is responsible for preparing the budgets allocated to these programs and projects.

2. Mayor of GAM: The Mayor of GAM is appointed by the Prime Minister of Jordan to 


\section{Macrothink}

International Journal of Human Resource Studies

ISSN 2162-3058 2020, Vol. 10, No. 2

direct the GAM council through implementing GAM programs and projects and building relationships and networks with outside stakeholders.

3. City Manager: This position is represented by the local administrator of Amman city, who is appointed by the Prime Minister following the GAM council's recommendation. The aim is to support the Mayor's responsibilities, implement the GAM strategies and plans to achieve its goals and to manage the GAM structure.

4. Deputy City Manager: This position shoulders all the responsibilities to achieve a set of strategic goals and indicators of a certain sector, as well as the related sub-strategies in a specific field.

5. Executive Managers (Directorate Managers): This position works under each sector to respond to the performance indicators according to the sector's work (GAM, 2015; Shaqrah, 2014; World Bank, 2017).

Basically, the context of GAM is organized by the Jordanian municipal law (adjusted in 2002) and other laws, regulations, and policies that organize all public organizations in the Jordanian context. Furthermore, the performance of GAM is managed by the strategic plan methodology (World Bank, 2017). GAM performance is described in the hierarchy of the strategic planning process of GAM as shown in Figure 2 (GAM, 2018a, P. 22).

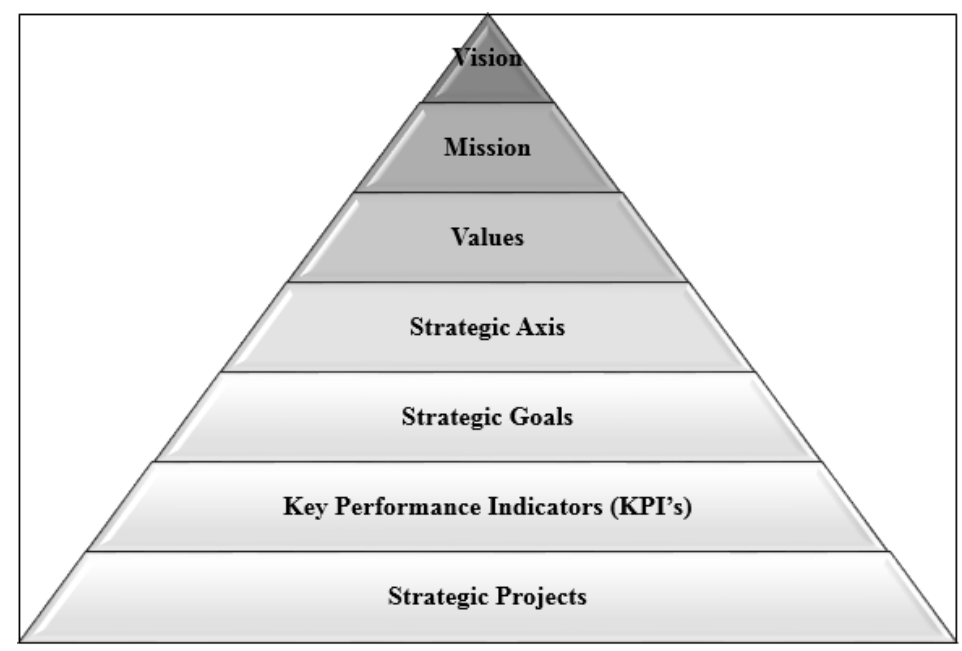

Figure 2. GAM Strategic Planning Process

Source: (GAM, 2018a, P. 22)

To regulate its performance, GAM internally develops the strategic planning process periodically every three years. This planning process started in 2002 and the last plan (2018-2020) was developed in 2018. The strategic planning process is organized through an internal methodology, which is the methodology of strategic planning (issued in April 2005, and adjusted in April 2008, October 2008, March 2010, and March 2013 editions). The GAM system might be described into four fields, including inputs and planning, goals setting, strategies and plans, and result publishing (GAM, 2018a) as shown in Figure 3. 


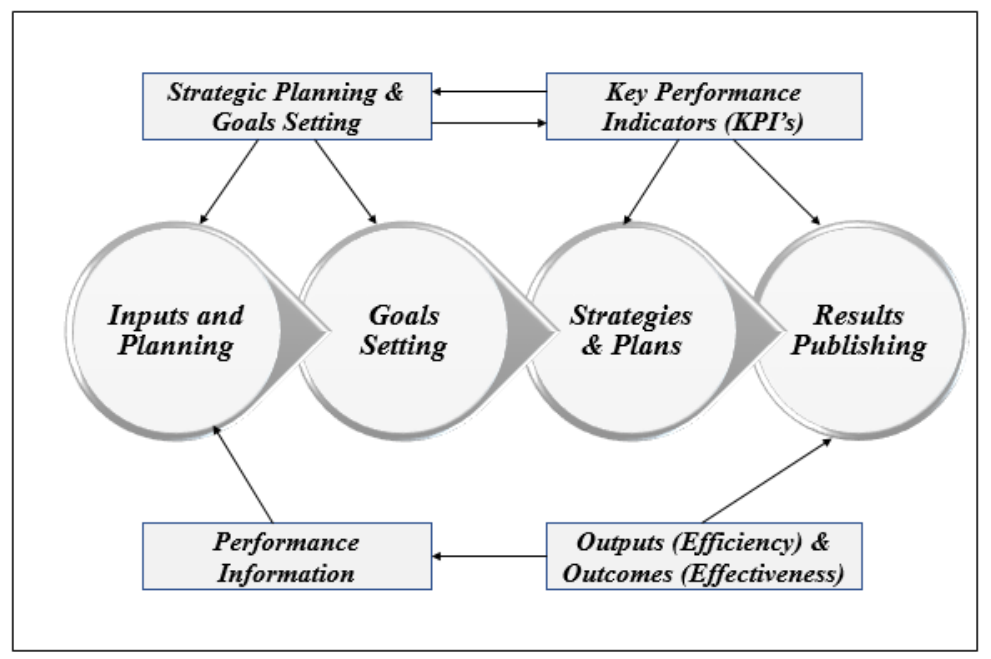

Figure 3. Performance Management System of GAM

Source: Strategic Plan of GAM (2018-2020)

\subsection{Inputs and Planning}

The PMS of GAM begins with the performance inputs and the planning field, which mainly focus on five major sources, including 1) the national goals, i.e., the set of national goals that stem from the national agenda of the Jordanian context, 2) the royal initiatives, i.e., the set of initiatives issued by His Majesty King Abdullah II, which are oriented to the citizens' interests and services, 3 ) the city growing plan, that is, the economic plan, which focuses on three major dimensions, including the economic growth vision, the set of policies that consist of several frameworks to develop the national economy, and the comprehensive charts to support the planning field at all levels within GAM, 4) the planning levels in Amman city, which focus on two levels of planning: the city level (Metropolis) and the regional level planning, and 5) the strategic purposes, which reflect project goals and seek to make Amman city an intelligent, attractive, green, cultural, an investable, and a liveable city that engages its citizens. These fifth sources represent the performance information and the sources for the goals setting field of the GAM system (GAM, 2015, P. 33-35).

\subsection{Goals Setting}

Based on the mentioned sources of performance information, GAM sets its strategic goals based on its vision and mission. This process has been cooperatively conducted with eight bodies within the GAM structure, including City Manager office, Organizational Excellence Directorate, and the six Deputies of the City Manager, who direct the GAM's sectors. The strategic goals and responsibilities are illustrated in Table 3. 
Table 3. The Strategic Goals of GAM and Their Responsibilities

\begin{tabular}{|c|c|c|}
\hline $\begin{array}{l}\text { Strategic } \\
\text { Dimension }\end{array}$ & Strategic Goal & Goal Responsibility \\
\hline \multirow{7}{*}{$\begin{array}{l}\text { Organizational } \\
\text { Performance }\end{array}$} & Raise the efficiency of human resource. & $\begin{array}{l}\text { Directorate } \\
\text { Resource }\end{array}$ \\
\hline & $\begin{array}{l}\text { Develop and automate the processes and } \\
\text { raise their efficiency. }\end{array}$ & \multirow{2}{*}{$\begin{array}{l}\text { Information Technology } \\
\text { Unit }\end{array}$} \\
\hline & $\begin{array}{l}\text { Develop the infrastructure systems of } \\
\text { information technology. }\end{array}$ & \\
\hline & $\begin{array}{l}\text { Improve and develop the quality of } \\
\text { public services. }\end{array}$ & \multirow{2}{*}{$\begin{array}{l}\text { Directorate r of } \\
\text { Organizational Excellence, } \\
\text { Directorate of Human } \\
\text { Resource, Environmental } \\
\text { Affairs Sector }\end{array}$} \\
\hline & $\begin{array}{l}\text { Provide an organizational environment } \\
\text { supports each of the development and } \\
\text { improvement. }\end{array}$ & \\
\hline & $\begin{array}{l}\text { Improve and develop connection ways } \\
\text { with the stakeholders. }\end{array}$ & $\begin{array}{l}\text { Directorate of Media and } \\
\text { Connection }\end{array}$ \\
\hline & $\begin{array}{l}\text { Enhance the control, inspection, and } \\
\text { develop the legislations. }\end{array}$ & Directorate of Legal Affairs \\
\hline \multirow{2}{*}{$\begin{array}{l}\text { Financial } \\
\text { Management }\end{array}$} & $\begin{array}{l}\text { Raise financial management according to } \\
\text { best practices in the public sector. }\end{array}$ & \multirow{2}{*}{$\begin{array}{lr}\text { Financial } & \text { and } \\
\text { Administrative } & \text { Affairs } \\
\text { Sector } & \end{array}$} \\
\hline & Raise the efficiency of the supply chain. & \\
\hline \multirow{4}{*}{ Public Works } & Raising of safety level in Amman City. & \multirow{4}{*}{ Public Works Affairs Sector } \\
\hline & $\begin{array}{l}\text { Developing and upgrading the efficiency } \\
\text { of public transport services. }\end{array}$ & \\
\hline & $\begin{array}{l}\text { Effective and efficient road and transport } \\
\text { network. }\end{array}$ & \\
\hline & $\begin{array}{l}\text { Improve, develop, and raise the readiness } \\
\text { of the assets and properties of (GAM). }\end{array}$ & \\
\hline \multirow{3}{*}{$\begin{array}{l}\text { Environment } \\
\text { and Public } \\
\text { Health }\end{array}$} & Increase the space green land to Amman. & \multirow{3}{*}{$\begin{array}{ll}\text { Environmental } & \text { Affairs } \\
\text { Sector \& Public } & \text { Health } \\
\text { Affairs Sector } & \end{array}$} \\
\hline & $\begin{array}{l}\text { Use sustainable practices and friendly } \\
\text { environment energy. }\end{array}$ & \\
\hline & $\begin{array}{l}\text { Provide health, safety, and a clean } \\
\text { environment. }\end{array}$ & \\
\hline \multirow[t]{2}{*}{$\begin{array}{l}\text { Planning and } \\
\text { Investment }\end{array}$} & $\begin{array}{l}\text { Plan, organize, and develop the city } \\
\text { grows as an efficient way and attains the } \\
\text { sustainable development. }\end{array}$ & \multirow[t]{2}{*}{ Economic Affairs Sector } \\
\hline & Guide and attract investment to Amman. & \\
\hline \multirow[b]{2}{*}{ Community } & Interact and involve the community. & \multirow[b]{2}{*}{$\begin{array}{l}\text { Social Development Affairs } \\
\text { Sector }\end{array}$} \\
\hline & $\begin{array}{l}\text { Contribute in develop the community } \\
\text { culturally, socially, and sportily, and } \\
\text { enhance each of the social responsibility } \\
\text { and citizenship. }\end{array}$ & \\
\hline \multirow[t]{2}{*}{ Identification } & $\begin{array}{l}\text { Maintaining Amman's identification and } \\
\text { properties. }\end{array}$ & \multirow{2}{*}{$\begin{array}{l}\text { Social Development Affairs } \\
\text { Sector }\end{array}$} \\
\hline & Make Amman center of tourist attraction. & \\
\hline
\end{tabular}

Source: Strategic Planning of GAM (GAM, 2015, P. 39)

Based on Table 3, the responsibilities to achieve GAM goals overlap with multiple bodies, for example, the organizational performance dimension, which overlaps with the environment and public health dimension. Also, the responsibilities overlap with multiple directorates in the same sector. Such interventions and overlapping are being addressed, managed, and organized using action plans, resource allocation, and initiatives (GAM, 2015). 


\subsection{Strategies and Plans}

After identifying the strategic goals of GAM, strategies and action plans are designed by the directorates of each sector to accomplish their own strategic goals. These strategies and plans are implemented through a set of Key Performance Indicators (KPIs) and designed according to the strategic goals of the sector's affairs. Additionally, these indicators are measured in two ways, including effectiveness and efficiency. Thereby, describing the GAM's KPIs is essential to highlight the mechanism for measuring its indicators. This description is illustrated in detail in Table 4 (GAM, 2015).

Table 4. Description of Key Performance Indicators (KPIs) of GAM

\begin{tabular}{|c|c|c|c|}
\hline Strategic Goals & $\begin{array}{l}\text { Number } \\
\text { of KPI's }\end{array}$ & $\begin{array}{l}\text { Effectiveness } \\
\text { (Quantitative) }\end{array}$ & $\begin{array}{l}\text { Efficiency } \\
\text { (Qualitative) }\end{array}$ \\
\hline Raise the efficiency of human resource. & 14 & 1 & 13 \\
\hline $\begin{array}{l}\text { Develop and automate the processes and raise } \\
\text { their efficiency. }\end{array}$ & 10 & 3 & 7 \\
\hline $\begin{array}{l}\text { Develop the infrastructure systems of } \\
\text { information technology. }\end{array}$ & 9 & 8 & 1 \\
\hline $\begin{array}{l}\text { Improve and develop the quality of public } \\
\text { services. }\end{array}$ & 6 & 3 & 3 \\
\hline $\begin{array}{l}\text { Provide an organizational environment } \\
\text { supports each of the development and } \\
\text { improvement. }\end{array}$ & 11 & 4 & 7 \\
\hline $\begin{array}{l}\text { Improve and develop connection ways with the } \\
\text { stakeholders. }\end{array}$ & 9 & 3 & 6 \\
\hline $\begin{array}{l}\text { Enhance the control, inspection, and develop } \\
\text { the legislations. }\end{array}$ & 17 & 11 & 6 \\
\hline $\begin{array}{l}\text { Raise financial management according to best } \\
\text { practices in the public sector. }\end{array}$ & 14 & 6 & 8 \\
\hline Raise the efficiency of the supply chain. & 7 & 0 & 7 \\
\hline Raising of safety level in Amman City. & 12 & 9 & 3 \\
\hline $\begin{array}{l}\text { Developing and upgrading the efficiency of } \\
\text { public transport services. }\end{array}$ & 9 & 8 & 1 \\
\hline $\begin{array}{l}\text { Effective and efficient road and transport } \\
\text { network. }\end{array}$ & 10 & 8 & 2 \\
\hline $\begin{array}{l}\text { Improve, develop, and raise the readiness of } \\
\text { the assets and properties of (GAM). }\end{array}$ & 8 & 7 & 1 \\
\hline Increase the space green land to Amman. & 5 & 3 & 2 \\
\hline $\begin{array}{l}\text { Use sustainable practices and friendly } \\
\text { environment energy. }\end{array}$ & 3 & 3 & 0 \\
\hline $\begin{array}{l}\text { Provide health, safety, and a clean } \\
\text { environment. }\end{array}$ & 17 & 10 & 7 \\
\hline $\begin{array}{l}\text { Plan, organize, and develop the city grows as } \\
\text { an efficient way and attains the sustainable } \\
\text { development. }\end{array}$ & 4 & 2 & 2 \\
\hline Guide and attract investment to Amman. & 4 & 3 & 1 \\
\hline Interact and involve the community. & 4 & 3 & 1 \\
\hline $\begin{array}{l}\text { Contribute in develop the community } \\
\text { culturally, socially, and sportily, and enhance } \\
\text { each of the social responsibility and } \\
\text { citizenship. }\end{array}$ & 8 & 5 & 3 \\
\hline $\begin{array}{l}\text { Maintaining Amman's } \\
\text { properties. }\end{array}$ & 8 & 2 & 6 \\
\hline Make Amman center of tourist attraction. & 11 & 8 & 3 \\
\hline Total & 200 & 110 & 90 \\
\hline
\end{tabular}

Source: Strategic Planning of GAM (GAM, 2018a, P. 28-32; GAM, 2015, P. 54-72) 
It has been observed that more than half of GAM's KPIs are reliant on the effective measures to gauge the GAM's performance (i.e., the quantitative indicators). However, the efficiency measures (i.e., the qualitative indicators) stand for less than half of the GAM's KPIs. In particular, the quantitative indicators (i.e., the statistics indicators) are massively contributed to the outcomes of GAM's strategic goals, which are mainly used to gauge the quality of public services delivered. Also, both types of the GAM's indicators are quarterly used to gauge the progress achievement internally for the strategic goals of GAM every year from 2013 to 2017 in two separate strategic plans (GAM, 2015, P. 54-72).

\subsection{Publishing the Results}

The last field of the GAM system involves publishing the results. It has been achieved by making the results of GAM strategic goals and indicators available to the public through the yearly publishing of the performance indicators' results that are linked with the strategic goal. The next target values of each indicator are linked with the strategic goal for the next plan (i.e., the next three years), which are available as well (see the Tables of the strategic goals indicators: GAM, 2015, P. 54-72). Finally, regarding the evaluation of the results of its indicators, GAM surveys the public satisfaction via its website every year with an update of using new measures to gauge the new tasks that are achieved according to its plans (GAM, 2018b).

\section{Evaluation of the GAM System}

Scholars have emphasized that public organizations are not established for-profit purposes (Roge \& Lennon, 2018). It has been confirmed that these organizations are operated and established to deliver quality public services to accomplish public satisfaction (Andersen et al., 2016). In other words, they focus on achieving quality, efficiency, and effectiveness of the public organization's performance (Demartini \& Mella, 2014; Modell, 2015). Besides, public organizations should embed the feedback of the public during the performance setting process because it is a valuable source to improve performance (Spekle \& Verbeenten, 2014; Yan \& Ting, 2018). Moreover, academics and practitioners have clearly stated that public organizations could collect the public satisfaction by formal bodies such as community representatives, taxpayer bodies, and other formal bodies to introduce valuable performance information by the public (Denhardt \& Denhardt, 2000; Ohemeng et al., 2018; Parker et al., 2019; Roh, 2018). Concerning this status, GAM continuously conducts a public satisfaction survey on its website to gauge public satisfaction of services delivered. However, it is obvious that based on the first field of the GAM system (i.e., inputs and planning), GAM might not embed and consider the results of the community satisfaction survey as a source of performance information in the inputs and planning field of its system.

Also, scholars explained that the archival indicators, which are used to measure the performance effectiveness (i.e., outcomes), are not useful to foster the performance of public organizations because these indicators rely on administration and official records. The archival indicators usually neglect the efforts of external stakeholders to improve the performance of public organizations; they do not truly reflect the contributions of perceptual indicators that concentrate on the stakeholders' feedback (Andersen et al., 2015; Favero \& 
Bullock, 2014; Roge \& Lennon, 2018). Nevertheless, the GAM system depends on its official and administrative records to design its indicators for five years in a row (see Tables: GAM, 2018a, P. 28-32; GAM, 2015, P. 54-72). Also, more than half of the performance measures that are used to gauge the strategic goals of GAM are quantitative measures as previously illustrated in Table 4. The quantitative measures might provide outcomes of performance (i.e., effectiveness), and they might not gauge the quality of public services delivered by GAM to the public. The quality of these services can be provided by the outputs of performance (i.e., efficiency).

Performance appraisal is used to differentiate between good and bad performance, whereas the reward and punishment system is used to reward good performance and punish bad performance. These two fields are crucial fields of the PMS to evaluate, motivate, and punish the performance of public organizations (Goh et al., 2015; Jurnali \& Siti-Nabiha, 2015; Otley, 1999). The GAM system clarifies the responsibilities of performance indicators as previously illustrated in Table 3; it also gauges the performance progress quarterly, but it neglects to appraise and evaluate the performance results of its indicators. There are no clear policies, standards, or procedures to reward and punish the obtained performance results and, therefore, the GAM system probably lacks accountability in distinguishing between good performance versus bad performance. Regarding the reward and punish system field, the absence of this field in the PMS might negatively affect staff performance and influence its motivation towards organizational performance. Due to the considerable emphasis by scholars that the good system must include these two fields to evaluate the performance results, reward the good performance, and punish or control poor performance (Jurnali \& Siti-Nabiha, 2015; Otley, 1999; Spekle \& Verbeeten, 2014; Verbeeten, 2008). Also, scholars have strongly confirmed that the reward and punish system of public organizations should take shape of structure or policy to illustrate the benefits and the consequences of the performance results (Aghaz et al., 2017; Markova \& Ford, 2011).

\section{Synthesis and Conclusion}

\subsection{Synthesizing a Comprehensive Framework of PMS}

Based on Otley's (1999) framework of PMS, it covers five major fields to achieve good performance results of any public organization, including strategic planning and goal setting, strategies and plans, performance appraisal, reward and punishment system, and performance information (Otley, 1999). Accordingly, the Pakistani system implements four fields, including organizational setup, performance indicators and benchmarks, analysis of performance information, and focus on performance management (Janjua et al., 2019). Although the Pakistani system is described as a successful experience in the developing world, it should focus on the qualitative measures due to the high concentration level on the budget allocation for designing its goals, which focus on the financial goals rather than non-financial goals. It has been confirmed that one of the critical premises of introducing NPM reforms involves owning clear measures and a strong emphasis on services (Fryer et al., 2009; Roh, 2018). Besides, the KPIs of this system include (300) quantitative indicators. This status makes the appraising process focuses on effectiveness, which, in turn, conceals the 
efficiency and quality of the services delivered by public organizations (Spekle \& Verbeeten, 2014). Scholars pointed out that the performance appraisal field needs to clarify the good and bad performance, whereas the reward and punishment field needs to embed a structure and policies to elaborate the benefits and consequences of the performance results (Roge \& Lennon, 2018; Verbeeten, 2008). Finally, the performance results of the Pakistani system are published online. It has been confirmed, however, that the community feedback on the quality of the delivered services can be regarded as a valuable source of gauging the performance information (Denhardt \& Denhardt, 2000; Parker et al., 2019).

On the other hand, the Indonesian system implements four fields of Otley's (1999) framework, including strategic planning, performance measurement, performance reporting, and utilize the performance information (Jurnali \& Siti-Nabiha, 2015). The strategic planning field is a translation process of the organizational vision, mission, goals, objectives, and strategies. This field should consider the medium and the long term at the national level. Also, the performance measurement needs to be conducted according to a systematic assessment of the performance indicators concerning inputs, outputs, outcomes, benefits, and implications to foster the entire performance and enhance both responsibility and accountability. The performance reporting field needs to be disposed of its concentration on financial aspects to achieve efficiency. Focusing on financial aspects might weaken the performance efficiency and quality. Alternatively, the Indonesian local government needs to focus on the results' orientation (i.e., the citizens' satisfaction) to achieve high-quality public services. Moreover, performance accountability can be controlled by clarifying performance indicators and the adoption of external assessment along with a self-assessment approach to foster the transparency concept. The performance information field of this system should cover several aspects of performance results, including measurement results, evaluation, analysis, failures and successes aspects, problems and barriers, and inputs and solutions. Apparently, this system ignores one of the most important fields of PMS, which is the reward and punishment system field. Also, the Indonesian system needs to collect and publish the performance results, and it should consider public feedback on its performance to improve the quality of services.

In the Thai context, the Thai system implements four steps, including the development of the results based on the management system, office establishment of the public sector development commission, the framework of the performance development agreement, and refining and extending performance agreement. Regarding the performance development agreement framework, the Thai system deals with four fields, including the results collection of goals and mission, gauging the public satisfaction of the services delivered, the resource allocation and reduction process, and the development methods used to foster the performance of public organizations (Sutheewasinnon et al., 2016). The strategic planning field has been implemented in the Thai system by introducing five components, including a results-based management system, a new government organization framework, rightsizing the civil services, improving human resource management (HRM), and establishing a senior executive development system. These components involve the description of the NPM reforms. The mentioned components should be able to respond to four perspectives, namely external, internal, innovation, and financial. The Thai system relies on the vision, mission, 


\section{MInstitute Macrothink}

International Journal of Human Resource Studies

ISSN 2162-3058 2020, Vol. 10, No. 2

and goals and considers public feedback on the quality of services delivered in the strategic planning field. The second field is the strategies and plans field. Although the Thai system designs processes to operate its performance, it might fail to clarify the utilization of performance indicators and the type of indicators that are used. The Thai system also evaluates the efficiency of the processes that are used to perform the task according to time, rapidity, and resource reduction. Besides, it conducts community satisfaction surveys to collect community feedback to be considered in the strategic planning field. However, the Thai system does not use the reward and punishment system field to motivate and punish the performance results.

Based on Otley's (1999) framework of PMS and following what has been previously discussed in the evaluation section of the GAM system and the current synthesis section, the PMS of any public entity should cover five major fields and related dimensions as shown in Figure 4. First, the strategic planning and goals setting field, including NPM reforms, resource allocation such as financial resource and HRM, national and community discourses, and organizational vision, mission, strategy, and goals. Second, the strategies and plans field, including sub-strategies, action plans, processes, and measurable performance indicators, which, in turn, might precisely achieve effectiveness, efficiency, and quality concepts. Third, the performance appraisal field, including policies, procedures, standards, and self-assessment, which, in turn, might control, monitor, assess the performance results; they will be useful to implement both responsibility and accountability concepts and differentiate between the good and bad performance results. Fourth, the reward and punishment system field, including policies, structure, benefits, and consequences. Fifth, the performance information field, including measurements and goals results, evaluation and analysis, community satisfaction feedback, and inputs and solutions, which, in turn, might foster the quality and transparency concepts. 


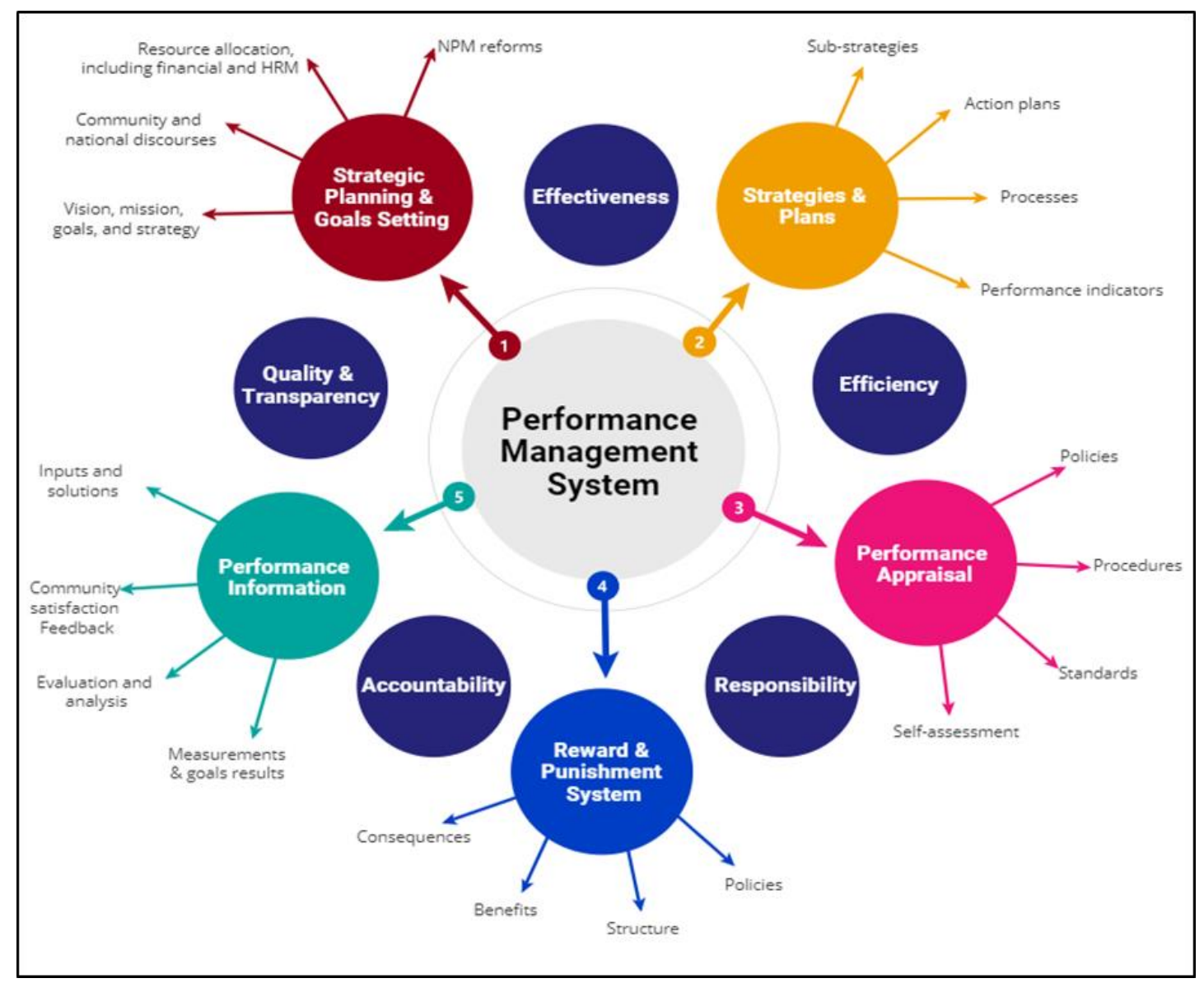

Figure 4. The Developed PMS Framework of Public Organizations

\subsection{Conclusion}

Based on the developed PMS framework of public organizations as shown in Figure 4, there exists a considerable emphasis by the Jordanian government on improving the performance of public organizations in Jordan. This has been reflected through a series of decisions that are related to the organizational performance reforms in the Jordanian public sector. These reforms were interpreted in the last decision, which embedded a set of instructions for this purpose by the Prime Minister of Jordan (No. 83\11\1\32197 - 2018) when he focused on improving and revisiting of the PMS of the Jordanian public sector (PMOJ, 2018).

However, GAM as one of the biggest employers of the Jordanian public sector has failed to engage the public contributions in its system as a key method to improve its performance and meet the public interests. This failure has led to excessive reliance on the archival indicators, which are not useful for the PMS of the public organizations. Besides, the quantitative measurements, which are vastly adopted in its system, might not be helpful to foster the quality of public services delivered. Accordingly, in line with the proposed PMS framework in this paper, the field of performance appraisal and the field of the reward and punish system of the GAM system are neglected. This status might weaken the GAM system and, therefore, poor services will be delivered by GAM to its community. Based on Otley's (1999) framework of PMS, in addition to the three experiences of implementing the PMS of public 
entities and the GAM system, the developed framework of PMS has been synthesized and proposed in this paper; it is explained in the synthesizing section.

To conclude, a detailed and in-depth investigation remains necessary to provide a clear reflection of the PMS experiences within the context of the Jordanian public organizations and the Middle East region as a key constituent of the developing world. This study contributes to the body of knowledge on PMS due to the on-going managerial transformation and because of the limited number of studies on the PMS area of the developing world (Janjua et al., 2019; Budhwar et al., 2019). Further PMS experiences will enrich the existing literature by adding significant sources in the performance area of the developing countries. Therefore, it is recommended to adopt the developed framework in this study for further studies on the performance area of public organizations.

\section{References}

Aghaz, A., Sheikh, A., \& Amirkhani, T. (2017). Human Resource Management in the Public Sector: An Investigation into the Iranian Ministries. Iranian Journal of Management Studies, 10(3), 667-695.

Akbar, R., Pilcher, R. A., \& Perrin, B. (2015). Implementing performance measurement systems: Indonesian local government under pressure. Qualitative Research in Accounting \& Management, 12(1), 3-33. https://doi.org/10.1108/QRAM-03-2013-0013

Andersen, L. B., Boesen, A., \& Pedersen, L. H. (2016). Performance in public organizations: Clarifying the conceptual space. Public Administration Review, 76(6), 852-862. https://doi.org/10.1111/puar.12578

Andersen, L. B., Heinesen, E., \& Pedersen, L. H. (2015). Individual performance: From common source bias to institutionalized assessment. Journal of Public Administration Research and Theory, 26(1), 63-78. https://doi.org/10.1093/jopart/muv010

Arnaboldi, M., Lapsley, I., \& Steccolini, I. (2015). Performance management in the public sector: The ultimate challenge. Financial Accountability \& Management, 31(1), 1-22. https://doi.org/10.1111/faam.12049

Budhwar, P., Pereira, V., Mellahi, K., \& Singh, S. K. (2019). The state of HRM in the Middle East: Challenges and future research agenda. Asia Pacific Journal of Management, 1-29.

Demartini, C., \& Mella, P. (2014). Beyond feedback control: the interactive use of performance management systems. Implications for process innovation in Italian healthcare organizations. The International Journal of Health Planning and Management, 29(1), e1-e30. https://doi.org/10.1002/hpm.2177

Denhardt, R. B., \& Denhardt, J. V. (2000). The new public service: Serving rather than steering. Public administration review, 60(6), 549-559. https://doi.org/10.1002/hpm.2177

Favero, N., \& Bullock, J. B. (2014). How (not) to solve the problem: An evaluation of scholarly responses to common source bias. Journal of Public Administration Research and Theory, 25(1), 285-308. https://doi.org/10.1093/jopart/muu020 
Fryer, K., Antony, J., \& Ogden, S. (2009). Performance management in the public sector. International Journal of Public Sector Management, 22(6), 478-498. https://doi.org/10.1108/09513550910982850

Goh, S. C., Elliott, C., \& Richards, G. (2015). Performance management in Canadian public organizations: findings of a multi-case study. International Journal of Productivity and Performance Management, 64(2), 157-174. https://doi.org/10.1108/IJPPM-10-2013-0170

Greater Amman Municipality. (2015). https://www.ammancity.gov.jo/. Retrieved from https://www.amman.jo/site_doc/statigicplan2015.pdf

Greater Amman Municipality. (2018a). https://www.ammancity.gov.jo/. Retrieved from https://www.amman.jo/site_doc/statigicplan2018.pdf

Greater Amman Municipality. (2018b). https://www.ammancity.gov.jo/. Retrieved from https://www.amman.jo/ar/gam/result.aspx

Janjua, A., Attique, F., Raza, A., \& Akbar, W. (2019). Effective performance management of local governments in Khyber Pakhtunkhwa, Pakistan. International Journal of Productivity and Performance Management, 68(1), 26-45. https://doi.org/10.1108/IJPPM-11-2017-0300

JESC, The Jordanian Economic and Social Council. (2018). http://www.esc.jo/. Retrieved from http://www.esc.jo/Documents/ESC-Report-Final.pdf/

Jurnali, T., \& Siti-Nabiha, A. K. (2015). Performance management system for local government: The Indonesian experience. Global Business Review, 16(3), 351-363. https://doi.org/10.1177/0972150915569923

Markova, G., \& Ford, C. (2011). Is money the panacea? Rewards for knowledge workers. International Journal of Productivity and Performance Management, 60(8), 813-823. https://doi.org/10.1108/17410401111182206

Modell, S. (2015). Performance measurement in the public sector. Wiley Encyclopedia of Management, 1-5. https://doi.org/10.1002/9781118785317.weom010057

Muath Freij, Amman municipality to include new districts to serve the rising population, The Jordan Times, 21 February 2016.

Municipality of Greater Amman. (2018). General information. Retrieved from https://jordan.gov.jo/wps/portal/Home/GovernmentEntities/Agencies/Agency/Municipality\% 20of\%20Greater\%20Amman?nameEntity=Municipality\%20of\%20Greater\%20Amman\&enti tyType=otherEntity

Ohemeng, F. L. K., Amoako Asiedu, E., \& Obuobisa-Darko, T. (2018). Giving sense and changing perceptions in the implementation of the performance management system in public sector organisations in developing countries. International Journal of Public Sector Management, 31(3), 372-392. https://doi.org/10.1108/IJPSM-05-2017-0136 
Otley, D. (1999). Performance management: a framework for management control systems research. Management accounting research, 10(4), 363-382. https://doi.org/10.1006/mare.1999.0115

Parker, L. D., Jacobs, K., \& Schmitz, J. (2019). New public management and the rise of public sector performance audit: Evidence from the Australian case. Accounting, Auditing \& Accountability Journal, 32(1), 280-306. https://doi.org/10.1108/AAAJ-06-2017-2964

Prime Minister Of Jordan. (2018). http://www.pm.gov.jo/. Retrieved from http://www.pm.gov.jo/upload/files/decision-2076.pdf

Radnor, Z. J., \& Barnes, D. (2007). Historical analysis of performance measurement and management in operations management. International Journal of Productivity and Performance Management, 56(5/6), 384-396. https://doi.org/10.1108/17410400710757105

Rautiainen, A., Urquía-Grande, E., \& Muñoz-Colomina, C. (2017). Institutional logics in police performance indicator development: a comparative case study of Spain and Finland. European Accounting Review, 26(2), 165-191. https://doi.org/10.1080/09638180.2015.1120412

Roge, K. M., \& Lennon, N. J. (2018). A study on the criteria of internal transparency, efficiency and effectiveness in measuring local government performance. Financial Accountability \& Management, 34(4), 392-409. https://doi.org/10.1111/faam.12176

Roh, J. (2018). Improving the government performance management system in South Korea: Focusing on central government agencies. Asian Education and Development Studies, 7(3), 266-278. https://doi.org/10.1108/AEDS-11-2017-0112

Shaqrah, A. (2014). The role of Greater Amman Municipality in the making of a knowledge city. European Scientific Journal, ESJ, 10(28).

Song, M., \& Meier, K. J. (2018). Citizen satisfaction and the kaleidoscope of government performance: How multiple stakeholders see government performance. Journal of Public Administration Research and Theory, 28(4), 489-505. https://doi.org/10.1093/jopart/muy006

Spekle, R. F., \& Verbeeten, F. H. (2014). The use of performance measurement systems in the public sector: Effects on performance. Management Accounting Research, 25(2), 131-146. https://doi.org/10.1016/j.mar.2013.07.004

Sutheewasinnon, P., Hoque, Z., \& Nyamori, R. O. (2016). Development of a performance management system in the Thailand public sector: Isomorphism and the role and strategies of institutional entrepreneurs. Critical Perspectives on Accounting, 40, 26-44. https://doi.org/10.1016/j.cpa.2015.06.002

Verbeeten, F. H. (2008). Performance management practices in public sector organizations: Impact on performance. Accounting, Auditing \& Accountability Journal, 21(3), 427-454. https://doi.org/10.1108/09513570810863996 


\section{Macrothink}

International Journal of Human Resource Studies

ISSN 2162-3058 2020, Vol. 10, No. 2

World Bank. (2017). Greater Amman Municipality, Jordan - Public Expenditure and Financial Accountability (PEFA) Assessment (English). Washington, D.C.: World Bank Group. Retrieved from http://documents.worldbank.org/curated/en/292151513880097520/Greater-Amman-Municipa lity-Jordan-Public-Expenditure-and-Financial-Accountability-PEFA-Assessment

Yan, H., \& Ting, Y. (2018). The Effectiveness of Online Citizen Evaluation of Government Performance: A Study of the Perceptions of Local Bureaucrats in China. Public Personnel Management, 47(4), 419-444. https://doi.org/10.1177/0091026018767475

ZAWYA. (2018). Greater Amman Municipality: Company Profile. Retrieved from https://www.zawya.com/mena/en/company/Greater_Amman_Municipality-1001694/

\section{Copyright Disclaimer}

Copyright for this article is retained by the author(s), with first publication rights granted to the journal.

This is an open-access article distributed under the terms and conditions of the Creative Commons Attribution license (http://creativecommons.org/licenses/by/4.0/). 